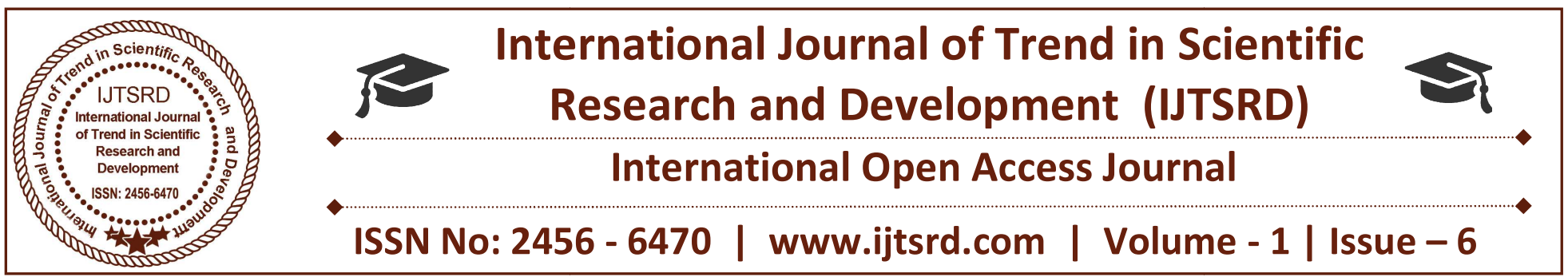

\title{
Agriculture Role of Indian Economy
}

\author{
G. Vijaya Bhaskar \\ PGT Economics, Telangana State Model School, \\ Nidmanoor, Nalgonda, Telangana, India
}

\section{ABSTRACT}

Today, India has walked on from sustenance security to nourishment adequacy and has appeared nourishment sway. All these have turned out to be conceivable attributable to the utilization of bleeding edge of science combined with the positive arrangement support and responsibility of rural research intellectual elite and Indian ranchers alike. The part of progressive focal and state governments as different plans and plans with respect to venture, innovation exchange and different viewpoints have vitalized rural development and rustic advancement. The Green Revolution innovations and the progression arrangements have contributed hugely to the Indian economy by giving sustenance independence and enhanced provincial welfare. The part of agrarian researchers has been demonstrated basic in such manner.

\section{INTRODUCTION}

Horticulture is the most imperative division of Indian Economy. Indian agribusiness area represents 18 for every penny of India's total national output (GDP) and gives work to half of the nation workforce. India is the world's biggest maker of heartbeats, rice, wheat, flavors and zest items. India has numerous regions to decide for business, for example, dairy, meat, poultry, fisheries and nourishment grains and so on. India has risen as the second biggest maker of foods grown from the ground on the planet [1]. As indicated by the information gave by Department of Economics and Statics (DES) the generation of nourishment grains for the year 2013-2014 is 264 million tons which is expanded when contrasted with (2012-2013) 257 million tons. This is a decent side effect for the
Indian economy from the farming area. India stays among fundamental three to the extent creation of various agrarian things like paddy, wheat, beats, groundnut, rapeseeds, common items, vegetables, sugarcane, tea, jute, cotton, tobacco leaves et cetera. Then again, on promoting front, Indian agribusiness is so far facing the issues, for instance, low level of business segment compromise and joining, accessibility of tried and true and helpful data required by ranchers on various issues in cultivating [2].

\section{Agriculture in Indian Economy}

Indian is a horticulture based nation, where over half of populace is rely upon agribusiness. This structures the primary wellspring of wage. The dedication of agribusiness in the national wage in India is more, along these lines, it is said that farming in India is a spine for Indian Economy. The commitment of agribusiness in the underlying two decades towards the aggregate national yield is in the vicinity of $48 \%$ and $60 \%$. In the year 2001-2002, this commitment declined to simply around $26 \%$. The total Share of Agriculture and Allied Sectors, Including agribusiness, trained creatures, and officer administration and fishery sub fragments the extent that rate of GDP is 13.9 percent amid 2013-14 at 2004-05 costs. Farming fares constitute a fifth of the aggregate fares of the nation. In context of the mindboggling position of the Agricultural Sector, assembling and support of Agricultural Statistics expect extraordinary hugeness. As indicated by the fourth Advance Estimates of Production of nourishment grains for 2013-14, total sustenance grain creation is evaluated to be 264.77 million tons 
(MT). Fare of flavors from India are depended upon to achieve US\$ 3 billion by 2016-17, on the back of innovative advancing techniques, imaginative packaging, quality in quality and an in number assignment framework. The Indian flavors business is pegged at Rs 40,000 crore (US\$ 6.42 billion) consistently, of which the stamped divide speaks to $15 \%$ [3]. The National Food Security Mission (NFSM) was propelled from Rabi, 2007-08. The key focuses of the National Food Security Mission (NFSM) is to grow generation of rice, wheat, beats and coarse grains through district expansion and effectiveness redesign supportably in the perceived area of the country; reestablishing soil readiness and benefit at the individual farm level; and enhancing ranch level economy (i.e. farm benefits) to reestablish certainty among the agriculturists. The Mission met with a stunning accomplishment and achieved the concentrated on additional age of rice, wheat and heartbeats. The Mission is being kept in the midst of Twelfth Five Year Plan with new concentrations of additional age of sustenance grains of 25 million tons including 10 million tons of rice, 8 million tons of wheat, 4 million tons of heartbeats and 3 million tons of coarse oats before the finish of twelfth five year design [4]. Preparing is an essential methodology of limit working of individuals as to upgrade the execution. Thusly, preparing needs evaluation is basic to the preparation procedure. It serves to perceive show issues what's more, future challenges to be met through preparing and change. It is obliged to make sense of the necessities of individual learner on which capable abilities should be gathered to do the consigned occupation in the affiliations [5]. The 6\% of agrarian generation is changed over in to prepared sustenance, which is engaged to accomplish $20 \%$ in coming future. The business is work raised and contributes around half for mechanical creation. Multi-National Food Companies have accepted a piece of influencing business division to draw and contention. Choice of innovative and test packaging techniques by nourishment industry has engaged the collecting of shielded and quality sustenance [6].

\section{CONCLUSION}

The majority of the Indians are specifically or by implication relying upon the agribusiness. Some are specifically connected with the cultivating and some other individuals are engaged with working with these merchandise. India has the ability to create the sustenance grains which can have immense effect in Indian Economy. To accomplish focused on stamp by the administration it needs to offer help if there should be an occurrence of land, bank credits and different hardware to the little agriculturists alongside the huge ranchers with this we can anticipate some change in Indian economy. 